\title{
FIRST RECORD OF TWO SPECIES OF LABOULBENIACEAE FOR BRITAIN.
}

\author{
By Professor R. H. Biffen, M.A.
}

Stigmatomyces purpureus Thax. On specimens of Scatella, collected on the coast of North Cornwall by Mr. C. G. Lamb, Cambridge.

Laboulbenia vulgaris Peyr. On various hosts, chiefly Bernbidium, Durnford Fen, Cambridge.

The specimens were kindly identified by Professor R. Thaxter.

\section{WHAT IS HYGROPHORUS CLARKII BERK. \& BR.?}

\author{
By M. C. Cooke.
}

It was during the year 1868 that Mr. J. A. Clark, of Street Somerset, sent to Mr. Worthington G. Smith, some specimens of a grey Hygrophorus, of which he made sketches, (dated October 5, I868), and then forwarded the specimens to the Rev. M. J. Berkeley for determination and description. Afterwards, it is presumed, this species was described in the Annals of Natural History for May, 1873, p. 340, No. I 358, under the name of Hygrophorts Clarkii B. \& Br., with the following brief and imperfect description :- ' Fragile; pileus convex, sub-umbonate, livid-cinereous, viscid, margin even; stem concolorous hollow; gills broad, distant, thick, adnate, white. In woods, October. Gills in large specimens nearly $\frac{1}{2}$ inch wide."

It will be observed that no dimensions are quoted and no figure mentioned.

Thus it remained, and no more, apparently, was heard of it, until about 1888, when a figure was published in Cooke's Illustrations of British Fungi, plate 934, fig. A., under this name, and afterwards quoted, with the original description, in Cooke's Handbook of British Fungi, 2nd. Edition I 889, p. 297.

This was assumed, at the time, to be a correct representation of the species in question ; but, on what evidence, and by what authority, it is impossible now to discover, as no note can be found, and my memory fails to render me any assistance, but no one could contend that it did not answer to the very meagre 